CZU: 821.111-3.09

https://doi.org/10.52505/lecturi.2021.05.15

\title{
ACADEMIC CONFRONTATIONS AT THE END OF HIGH MODERNITY
}

\author{
Felix NICOLAU \\ Universitatea Complutense din Madrid, Spania
}

\begin{abstract}
Academic novel is by definition a cultural enterprise, but it can properly surprise the hostility of an extremely hierarchical environment. Concepts, ideas and archetypes are preserved and melted in the literary substance even with the help of irony and pastiche. Or, better said, irony and pastiche are means of avoiding the hostility of a milieu blocked in stereotypes and snobbery.

Kingsley Amis 's novel "Lucky Jim" absorbs modernist cultural ingredients in order to demythologize them in a postmodern fashion. Anyway, it seems that the process of demythization implies the subsequent process of re-mythization. The cultural heritage is unavoidable in the last phase of postmodernism. In 1975 we can hardly speak about cultural aphasia. The individual with a postmodernist Weltanschauung plays the satirical role of the knight errant in search of falsified (dragonized) modernist mentalities and cultural options. This paper will analyse the risks and methods of demythization and the reverse process in an attempt to understand the cultural logic of antimodernist approaches.
\end{abstract}

Keywords: hierarchy, Lucky Jim, Kingsley Amis, postmodernism, academic hostility.

Rezumat. Romanul academic este prin definiție o întreprindere culturală, dar poate surprinde în mod corespunzător ostilitatea unui mediu extrem de ierarhic. Concepte, idei și arhetipuri se păstrează și se topesc în substanța literară chiar și cu ajutorul ironiei și pastișei. Sau, mai bine spus, ironia și pastișa sunt mijloace de a evita ostilitatea unui mediu blocat în stereotipuri și snobism.

Romanul lui Kingsley Amis, „Lucky Jim”, absoarbe ingrediente culturale moderniste pentru a le demitiza într-o manieră postmodernă. Oricum, se pare că procesul de demitizare presupune procesul ulterior de re-mitizare. Moștenirea culturală este inevitabilă în ultima fază a postmodernismului. În 1975 cu greu se poate vorbi despre afazie culturală. Un individ cu o viziune asupra lumii postmoderniste joacă rolul satiric al cavalerului rătăcit în căutarea unor mentalități și opțiuni culturale moderniste falsificate (dragonizate). Această lucrare va analiza riscurile și metodele demitizării și procesul invers în încercarea de a înțelege logica culturală a abordărilor antimoderniste.

Cuvinte-cheie: ierarhie, Lucky Jim, Kingsley Amis, postmodernism, ostilitate academică. 
„Think of the people who do kind things in an unkind way!" (Bernard Shaw, Plays Pleasant, You Never Can Tell, Penguin Books, London, 1958, p. 288)

Lucky Jim, 1954, by Kingsley Amis, is considered by everyone an extremely funny academic novel; a novel of the genre. A third millennium close reading may uncover, however, side-meanings at the time of publication which, in the meantime, have become central meanings. The humoristic ingredient of the novel has dwindled dramatically, whereas the underestimated conflict between modernist rituals and postmodernist reactions has spiralled upwards. This submerged dialectic can be made more obvious with the help of an analysis realized with the instruments of the cultural studies. The humour-embalmed hostility is rooted in an academic milieu which favours mediocrity and intellectual submission, if not sheer flattery.

\section{CENTRAL VERSUS PERIPHERAL MENTALITIES}

From the first pages of the novel we are shown the old-fashioned type of provincial life, when compared to the life in London. Provincial life depends on ritual, sophistication and uncompromising hierarchy. The tip of the iceberg is represented by those academics who want to be perceived not only as selfdemanding professionals, but as arty high-brow intellectuals. The masked crisis is generated by their snobbish amateurism. They want to be modern and sophisticated when, in fact, they are only conventional. Christopher Butler insisted on the de-familiarizing side of modernism, in line with the Russian formalists' ostranenie: „modernist art is far more indirect - it can make the world seem unfamiliar to us, as rearranged by the conventions of art" (Butler, 2010, p. 2). Mimicking modernism, which means frequenting art in a polite and conventional way, can trigger a comedy of situation, but not spiritual shivers.

Professor Welch impersonates all these cultural habits of provincial highlife society. As David Lodge remarked „Amis drew an immortal portrait of the absent-mindedness vanity, eccentricity and practical incompetence that academic institutions seem to tolerate and even to encourage in their senior stuff (or, at least, did before the buzz-word 'management' began to echo through the groves of academe in the 1980s)" (Amis, 2000, p. VIII).

A first opposition to the stiff-upper-lip-ness of late-modernism was the arrival of The Angry Young Men in 1950s. Amis's protagonist is a direct descendent of these university educated, but of humble social extraction, individuals. He is a "hero of humble origins ill-at-ease in a university milieu" (Ibidem, p. IX). In the Introduction to the 2000 edition of the novel, David Lodge remarked that "Jim is ill-at-ease and out of place in the university because he does not at heart subscribe 
to its social and cultural values, preferring pop music to Mozart, pubs to drawing rooms, non-academic company to academic" (Ibidem, p. XI). Later on, Lodge's charismatic Professor Zapp will master both academic culture and pop hits or cartoon series. Proficiency in these opposed cultural fields is a later date gain. The emergent postmodernism is not as tolerant as the full-blown postmodernism will be: "It is part of Jim's loathing for all high-cultural affectation that he will never admit, even to himself, to remembering the names of the books and authors he has read" (Ibidem, p. XIV). Jim plays the ignorant in a conscious and purposeful manner, preferring to be peripheral in the universe of academe, but central in the world of non-conventional, updated intellectuals.

\section{BAD HABITS, SOFT DRUGS, LESS WORK}

Actually, Jim Dixon is not bothered by the challenges in intellectual life, but by the amateurishness and empty ritualistic style of its protagonists. Between him and the rigid intellectual milieu there is an outsmarting competition. The young faculty member has an untidy aspect, but he cannot be taken for an idiot, not even for a Dostoyevskian mystical idiot. Sally Shuttleworth described the pre-modern type of idiot: "The idiot in mid-nineteenth-century culture was a figure of ontological indeterminacy, not only crossing boundaries, but troubling and disturbing them: at once animal and human, child and adult; an adult who is always childish, and a child who is never a child" (Shuttleworth, 2001, p. 17). The postmodern outcast does not have such an outstretched personality. In fact, his existence is quite transparent, as he functions as a critical mirror for the other characters. The readers are only informed that he enjoys smoking and light-drinking, that he mimics ludicrous people and plays all sorts of practical jokes. He even dares to drink in a bus full of students, who were drinking in their turn (Amis, 2000, p. 155). Regarding his other bad habit: "As long as he could remember he'd never been able to smoke as much as he wanted to" (Ibidem, p. 154). The new type of intellectual has very many habits specific to the emerging counterculture.

When it comes to writing academic articles, Jim tries to improvise and remix data: he ,cheered up at the thought of being able to do himself so much good without having to think at all" (Ibidem, p. 166). Postmodernism is less creative than prone to corroborate and shuffle previous creations. Fact is, neither his colleagues bring forth peremptory evidence about their creativity or sagacity. All along the plot we are informed about one article written by Jim but its publication is indefinitely postponed, until the editor of the respective academic magazine will publish it in his name. The omniscient narrator abruptly describes Dixon's intellectual policy: "to read as little as possible of any given book" (Ibidem, p. 17). This does not mean 
a rejection of reading as such, but a strategy of fast and various reading of as many books as possible with the purpose of staying tuned and informed in different fields. The new type of culture is characteristic for the postmodernist versatile approach to culture.

\section{HOW INTELLECTUAL ARE THE INTELLECTUALS OF THE} 50S?

The issue is: what is an intellectual like in the 50s? The more professor Welch parades his arty inclinations, the more Jim Dixon considers him and Bertrand, Welch's son and a mediocre painter, „stock platitudes” (Ibidem, p. 51). Welch is involved in all sort of artistic activities and sees himself as a gifted dilettante. Jim, in exchange, ventures deprecatory appreciations upon his superior's shallow personality: „Desperately he tried to listen to Welch's song, to marvel at its matchless predictability, its austere, unswerving devotion to tedium" (Ibidem, p. 64). Without being a connoisseur, the all-encompassing snobbery determines Jim to discard even masterpieces and geniuses: „The piece was recognizable to Dixon as some skein of untiring facetiousness by filthy Mozart” (Ibidem, p. 63). Actually, Dixon's attitude is not anti-intellectualist, but against artsy amateurish pretentions. He foregrounds the anti-aestheticism of a later date: „The high-water mark of anti-aestheticism arguably coincident with the emergence of the so-called 'culture wars' of the late 1980s and early 1990s, wherein anxieties concerning the erosion of the high culture/ popular culture divide gained considerable publicity and became an industry in their own right, though mostly, it has to be said, the preoccupation of media pundits rather than academics" (Joughin, 2003, p. 4). What is an intellectual about, anyway, in this context? It seems that the traits of British provincial intellectuals in the 50s are snobbery, social sophistication and hierarchical mentality. Their productivity consists of correct, but mediocre articles, and once in a while books, especially compilations. These are the pillars of a decrepit modernism, figment of social respectability, but not of originality and profundity.

The approach is a Hegelian one: ,the extension of universality implies the erasure of difference, and the notion of mediation implies that universality and difference can be reconciled only through the subordination of the difference to universality; harmony is thus achieved through domination and mediation turns out to be the erasure of difference rather than its recognition" (Butler, 1992, p. 4). Indeed, what suffocates Jim is the lack of recognition which is caused by his inability to wear a ,serious" mask. In order to contain his disgust in relation to the intellectual pretentions surrounding him, he braces up in a binge drinking manner. These evasionist tendencies offer Kingsley Amis the opportunity to exaggeratingly 
insist on physical disasters. Only some similes are fortunately-chosen: „his mouth had been used as a latrine by some small creature of the night, and then as its mausoleum" (Amis, 2000, p. 61).

There is no social implication or establishment contestation in the life of these intellectuals. Modernism disputed tradition whereas the nascent postmodernism enlarged the scope of culture by giving the accolade to counterculture and even to underculture. In this complex context, the aequa anima and the conformism of the „big-wigs” in the city seems suspect. Can authentic intellectuals remain so passive or closed to experiment? The inflexibility of their mentality is reflected by Bertrand, who always uses two 'No's to negate and these ones accompanied by a very suggestive non-verbal posture (Idem, ibidem). If „,every aspect of life has a politics" (Berube, 2002, p. IX), as postmodernism proclaimed, then there is very little postmodernism in the novel. Nor does the intellectual ebullition characterize these academics. In Berube's terms, they do not qualify for the intellectual caste: "for me, the term intellectual has come to mean something different, not necessarily a creator of culture, but one who deals specifically in the realm of ideas" (Ibidem, p. 6).

\section{MELTING THE SOLIDS}

In postmodernism intellectuals were supposed to de-congeal the fossilized structures of modernism. In its turn, modernity had triggered a liquefying process and this favoured the melting of spatialized representations: „Fluids, so to speak, neither fix space, nor bind time. In a sense, solids cancel time; for liquids, on the contrary, it is mostly time that matters. Was not modernity a process of 'liquefaction' from the start?" (Bauman, 2000, p. 2). Once modernism lost its flexibility and intellectual alertness, it was the turn of postmodernism to take over; to demythologize ,the 'profaning of the sacred': for disavowing and dethroning the past, and first and foremost 'tradition' - to wit, the sediment and residue of the past in the present; [...] to clear the site for new and improved solids; to replace the inherent set of deficient and defective solids with another set" (Ibidem, p. 3). The modernist intellectuals are reduced to the status of museum exhibits in postmodernism. Accordingly, they lost the dynamism of the intellectual condition and became sediments: „Rigidity of order is the artefact and sediment of the human agents' freedom" (Ibidem, p. 5). Re-fluidization of space is symbolized by Jim's funny faces when ridiculing his betters or colleagues. There is a whole collection of twisted, mocking faces in the novel, like a broken, extreme-baroque architecture. When Jim pulls faces, he externalizes his inner monologue in non-verbal communication. When this would be too dangerous, he transfers it inwardly: "mentally, however, he was making 
a different face and promising himself he'd make it actually when next alone" (Amis, 2000, p. 8). Imagination can compensate for the repressed irritation. For instance, Welch drives in such a disastrous manner that Jim construes sophisticated penalties: „He pretended to himself that he'd pick up his professor round the waist, squeeze the furry grey-blue waistcoat against him to expel the breath, run heavily with him up the steps, along the corridor to the Staff Cloakroom, and plunge the too small feet in their capless shoes into a lavatory basin, pulling the plug once, twice, and again, stuffing the mouth with toilet-paper" (Ibidem, p. 9-10). When he is obliged to be part of Welch's arty week-end he drinks so heavily that during the night he unconsciously burns with a cigarette the bed sheets and the table in his sleeping room. He will manifest his relief in getting rid of the incriminatory objects like this: "In the junk-room he nudged aside an archery target, making his crazypeasant face at it - what flaring imbecilities must it have witnessed? - and dumped the table behind the screen" (Ibidem, p. 75).

Even the first elaborate dialogue with Christine Callaghan, his future girlfriend, whom he will snatch away from Bertrand Welch, irritates him to the degree of a provoking the face-twisting silent reply. He produces „his Chinese mandarin's face, hunching his shoulders a little”; this because „he disliked this girl and her boyfriend so much that he couldn't understand why they didn't dislike each other" (Ibidem, p. 69). This expressive non-verbal communication is accompanied, when Jim Dixon is alone, by rhythmical imprecations, meant to reflect Welch's artistic amateurishness: ,you ignorant clod, you stupid old sod, you havering slavering” or „you wordy old turdy old scum, you griping old piping old bum” (Ibidem, p. 87). When he hears somebody calling Professor Welch, he produces his „Martian-invader face” (Ibidem, p. 91). If he is successful in playing practical jokes upon his adversaries, he manifests his joy hyperbolically: ,he threw back his head and gave a long trombone-blast of anarchistic laughter" (Ibidem, p. 103). If not, he may compensate with „his lemon-sucking face” (Ibidem, p. 141). All these acting abilities have a criticising side and he is aware of this aspect: ,he thought what a pity it was that all his faces were designed to express rage or loathing" (Ibidem, p. 250). Besides his critical inclinations, Jim Dixon is a morphotic and a vengeful person. His character's strong points are the somehow mild spirit of revenge and his disinterestedness in obtaining financial advantages. His way of reacting to negative stimuli rediscovers the biological, as Judith Butler will demand fifty years later (Butler, 1992, p. 109). His disrespect towards hierarchy functions as a critique of essentialism, from a postmodern point-of-view: „The conventional way of understanding essentialism is a position that accepts the notion of a pregiven or pre-constituted identity" (Ibidem, p. 108). As Dixon seems impervious to 
theory, we have no reason to assume a postmodernist reaction from his part. Maybe postmodern, but not postmodernist! However, the democratic, corrosive and flexible approach is obvious. Zygmunt Bauman remarked the negative and contesting side of postmodernism: „The postmodern mind seems to condemn everything, propose nothing. Demolition is the only job the postmodern mind seems to be good at. Destruction is the only construction it recognizes" (Bauman, 2000, p. X). This remark is not completely disqualifying, as it admits the existence of a constructive demolition. It is a responsible freedom, like that of the art: ,the exhilarating freedom to pursue anything and the mind-boggling uncertainty as to what is worth pursuing and in the name of what one should pursue it" (Ibidem, p. VII). From this standpoint, Jim Dixon is an artist who attacks an art whose symbolism loses its polysemantism at a fast pace. It is an unstable interval, imbibed with an obnoxious minimalism: „How farcical it seems to fight for genuine art when one can no more drop anything incidentally without the dropped object being proclaimed art" (Ibidem, p. VIII). Such deregulatory passages intervene regularly in the history of culture. Modernity emerged on the stage in the same combative coordinates: ,The war against mystery and magic was for modernity the war of liberation leading to the declaration of reason's independence" (Ibidem, p. X).

\section{BETWEEN ESSENTIALISM AND LITERALISM}

Jim Dixon is an unintentional agent of postmodernity as he supports a desultory and dubious lifestyle, whereas he also criticizes and mocks the vain pretentions and lack of abilities of the others. His interior monologue is a cannonade against bad driving, petty domestic manias, male domination in couples, infidelities in love affairs, pecuniary arrangements, low professional performances, and so on and so forth. For instance, Dixon cannot stand those snobbish gatherings wherein Bertrand, the failed painter, uses phrases like: „contrapuntal tone-values” (Amis, 2000, p. 112). That is why he elopes with Bertrand's girlfriend and feels: „like a special agent, a picaroon, a Chicago war-lord, a hidalgo, an oil baron, a mohock" (Ibidem, p. 113). No remorse whatsoever! Modernism cultivated a vertical spirit of adventure; postmodernism preferred a horizontal, more physical one. The physicality of the young lecturer is highlighted during the fight with Bertrand, when he simply knocks his rival down. Being so physical, laid-back and self-indulgent, it is obvious that Dixon could not be fond of sophisticated or elitist art.

Postmodernist art is not against indirectness, but its message is friendlier as it is interspersed both with parody and sentimentality. Dixon hates the literalism of some of the historical articles he has to write. An example in point would be the "flatulent work on textile trades in the time of the Tudors" (Ibidem, p. 170). What is 
the issue here? „The hallmark of literalism is a text's ability to compel our attention to its physical features, and more generally, to make us think of language in terms of its material constituents" (Ashton, 2005, p. 5).

Neither is Jim Dixon an essentialist, nor a literalist, that is a realist. He likes plotting, farcical scenarios and dynamic repertories. This is a possible explanation of the title: Jim is lucky as he leaves the novel with the beautiful girlfriend of his pestering boss's son and with a job in London, which was offered him by Gore-Urquhart, Christine's influent uncle. Why does Gore-Urquhart choose him? On account of his qualifications? On the contrary: „It's not that you've got the qualifications, for this or any other work, but there are plenty who have. You haven't got the disqualifications, though, and that's much rarer" (Amis, 2000, p. 234). This is symptomatic of a new brave world: communicative skills supersede specialised professionalism. The post-industrial epoch encourages the tertiary sector: services and education understood as a profitable and productive activity: „Equally, the rapid decline of the primary and secondary sectors of the economy has negatively impacted men's employment and incomes" (Synnott, 2009, p. 1). Dixon likes teaching, but dislikes the servile implications of building an academic career. Actually, he does not want a career, but a casual job which will not invade his private life. It is the beginning of a free-style jobs interval; jobs, not professions. This does not mean necessarily an irresponsible attitude. Dixon is a responsible man as he is on the verge of losing Christine's affection because he wants to protect Margaret, a fellow-lecturer who repeatedly pretends to commit suicide and who throws fits of hysteria. Actually, he possesses an extra-sense which forbids him „being starchy” (Amis, 2000, p. 136). His stance in life is paradoxical: a medievalist who loathes scholasticism. Paradoxical and oxymoronic. His final public lecture gets him the push. He is supposed to glorify the Merrie England but, instead of making a bow to tradition, he appears on stage in an advanced state of intoxication and formulates shocking conclusions: ,it was about the most un-Merrie period in our history. It's only home-made pottery crowd, the organic husbandry crowd, the recorder-playing crowd, the Esperanto..." (Ibidem, p. 227). Not only shocking, but aberrant. His thinking process advances in conformity with a ricochet technique. Moreover, he feels possessed by an evil spirit who commands him to imitate the preposterous manners of speaking of Professor Welch and of the Principal. Dixon is a naturalborn parodist and pasticheur. In any case, he despises plagiarism. This is the initial phase of postmodernism. Only the last phase will accept the semi-plagiarism of arresting the foreign content but of watching it from a different angle. As a fresh postmodernist, Dixon distrusts ready-made explanations: „One of the best Ways of describing postmodernism as a philosophical movement would be as a form of 
scepticism - scepticism about authority, received wisdom, cultural and political norms, etc.” (Sim, 2001, p. 3).

\section{CONCLUSION}

Lucky Jim can be read as a narrative about the conflictual relationship of late modernism with the incipient postmodernism. As it is obvious from Professor Welch's and Jim Dixon's behaviours, the last phase of modernism was characterised by amateurishness, pretence, stiff-upper-lip-ness and lack of creativity, whereas the budding postmodernism adopted a superficial, all-criticising, improvising and laid-back, even debauched manner. The elitist attitude ends up as dry pastiche and mannerism. The new cultural direction absorbs consumerism and low-middle class appetites. In the same time, the rigid profile of provincial intellectual life loses ground in favour of metropolitan underculture. In terms of professional developments, low-qualification jobs take precedence over tedious, life-consuming respectable professions. What is gained in sincerity and frank sentimental manifestations is lost in refinement and ritual. The non-conformist protagonist of the novel behaves like a knight errant à rebours in the search of the last dragons' modernist dens. The question still hovers after so many years from the publication of the book: is Jim Dixon conscious about the theoretical implications of his chaotic life, infringing all academic rules, or his opposition and intoxicated demise are only a chance synchronization with the emerging zeitgeist, the postmodernism?

\section{Bibliographic references:}

1. AMIS, Kingsley, Lucky Jim, Penguin Books Ltd: London, 2000.

2. ASHTON, Jennifer, From Modernism to Postmodernism. American Poetry and Theory in the Twentieth Century, Cambridge University Press: New York, 2005.

3. BAUMAN, Zygmunt, Liquid Modernity, Polity Press: UK, 2000.

4. BERUBE, Maurice R., Bergin \& Garvey Beyond Modernism and Postmodernism, Essays on the Politics of Culture, Bergin \& Garvey, London, 2002.

5. BUTLER, Christopher, Modernism: A Very Short Introduction, Oxford University Press Inc.: New York, 2010.

6. BUTLER, Judith, "Poststructuralism and Postmarxism", in Diacritics, Vol. 23, No. 4. (Winter, 1993): 2-11.

7. BUTLER, Judith; Stanley Aronowitz; Ernesto Laclau; Joan Scott; Chantal Mouffe; Cornel West, "The Identity in Question", Discussion, October, Vol. 61, (Summer, 1992): 108-120. http://links.jstor.org/sici?sici=0162-2870\%28199222\%2961\%3C108\%3AD\%3E 2.0.CO\%3B2-V.

8. JOUGHIN, John J. and Simon Malpas (Eds.), The New Aestheticism, Manchester University Press: Manchester, 2003. 
9. SHUTTLEWORTH, Sally, “'So Childish and So Dreadfully Un-Childlike': Cultural Constructions of Idiocy in the Mid-Nineteenth Century". In Crossing Boundaries. Thinking through Literature, Edited by Julie Scanlon And Amy Waste, Sheffield Academic Press Ltd.: Sheffield, 2001.

10. SIM, Stuart, The Routledge Companion To Postmodernism, Routledge: London, 2001.

11. SYNNOTT, Anthony, Re-Thinking Men Heroes, Villains and Victims, Ashgate Publishing Company, UK, 2009 